10. Ovcharuk O.V. Kompetentnosti yak kliuchdof ormuvannia zmistu osvity // Stratehiia reformuvannia osvity Ukrainy. - Kyiv.: K.I.S. 10.2003. -295 s.

11. Ctefanyk V.S. Vyvodyly z sela. Rezhym dostupu: https://www.ukrlib.com.ua/books/ printit.php?tid=2316

12. Stefanyk V.S. Sama-Samisinka Rezhym dostupu: https://royallib.com/book/stefanik_vasil/ odnaodineshenka.html.

Одержано статтю: 8.10 .2019

Прийнято до друку: 5.11.2019

УДК 378.147:347.96

DOI: $10.15330 /$ esu. $1.85-91$
Валентина Мірошніченко,

доктор педагогічних наук, доцент,

Національна академія Державної прикордонної

служби України ім. Б. Хмельницького

(м. Хмельницький, Укоаїна)

Valentyna Miroshnychenko,

Doctor of pedagogical sciences, Associate Professor, National Academy of the State Border Guard Service of Ukraine named after Bohdan Khmelnytskyi

(Khmelnytskyi, Ukraine)

mvi2016@ukr.net

\title{
ВИКОРИСТАННЯ ІНТЕРАКТИВНИХ ТЕХНОЛОГІЙ У ПІДОТОВЦІ МАЙБУТНІХ ЮРИСТІВ
}

\section{USAGE OF INTERACTIVE TECHNOLOGIES IN TRAINING OF FUTURE LAWYERS}

У статті обтрунтовано доцільність використання інтерактивних технологій у підготовиі майбутніх юристів. Висвітлюються особливості традиійних та інновачійних педагогічних технологій. Метою інтерактивного навчання вважається створення педагогом умов навчания, за яких студент сам відкриватиме, здобуватиме й знания та здійснюватиме самопідготовку до професійної діяльності.

Автором зазиачено, ио дочільність використания інтерактивних технологій у підготовиі майбутніх юристів визначається специфічними особливостями цього процесу та вимогами, які пред'являе суспільство до професійних якостей фахівиів-юристів. Серед методів вивчення юридичних дисииплін виокемлюється метод “групового обговорення". Звертається увага, ио використання методу “групового обговорення" відповідає головному призначенню прочесу підготовки майбутніх юристів - розвитку самостійного юридичного мислення, комунікативних умінь та навичок, що є важливим для формування професіоналізму майбутнього юриста.

Ключові слова: майбутні юристи, студенти, педагогічні технології, інтерактивні технології, підготовка до професійної діяльності, метод “групового обговорення".

The article substantiates the expediency of using interactive technologies in the training of future lawyers. A direct correlation between the effectiveness of preparing future lawyers for professional activity and how well and properly selected forms and methods of training were found. The features of traditional and innovative pedagogical technologies are highlighted. The purpose of interactive learning is to create an educator of learning conditions under which the student will discover, acquire knowledge and carry out self-preparation for professional activity. A feature of interactive learning methods is to encourage participants in the educational process to be active and interact. Designing the process of training future lawyers requires a clear definition of the purpose, content, methods, techniques, means of this process, interconnections and interdependence between its participants. 
The author noted that the expediency of using interactive technologies in the training of future lawyers is determined by the specific features of this process and the requirements that society places on the professional qualities of legal professionals.

Among the methods of studying historical and theoretical legal disciplines is the method of "group discussion". Attention is drawn to the fact that the use of the "group discussion" method corresponds to the main purpose of the process of training future lawyers - the development of independent legal (professional) thinking, communication skills and skills, which is important for shaping the professionalism of the future lawyer. The "group discussion" method is integrated (complex), since it involves training on certain topics-complexes containing materials of related subjects.

Successful introduction of interactive technologies into the training of future lawyers requires a systematic work, which first requires reviewing the content of training of pedagogical staff in order to form their professional readiness to work in the conditions of interactive training; second, to bring the educational process closer to the real requirements of the future professional work of lawyers.

Key words: future lawyers, students, pedagogical technologies, interactive technologies, preparation for professional activity, method of "group discussion".

Постановка проблеми у загальному вигляді та іï зв'язок із важливими науковими чи практичними завданнями. Професія зобов'язує майбутніх юристів вникати в усі сфери суспільного життя, зокрема - правову. Під час дослідноекспериментальної роботи нами було виявлено пряму залежність між результативністю підготовки майбутніх юристів до професійної діяльності і тим, наскільки вдало та грамотно підібрані форми та методи навчання, наскільки можна говорити про наявність у цьому процесі педагогічної технології як “майстерності навчання". Це спричинило актуальність виділення доцільності використання інтерактивних технологій у підготовці майбутніх юристів.

Аналіз останніх досліджень і публікацій, в яких започатковано розв'язання порушеної проблеми і на які спирається автор. Проблема підготовки юристів до професійної діяльності не є новою (А. Андрощук, С. Безсмолий, А.Борейчук, С.Пелипчук, Є.Тягнирядно). Окремі аспекти проблематики розглядають у своїх працях А. Борейчук, М. Козяр, О.Федоренко, Г. Яворська. Зокрема, С. Болоніна, О. Срмакова, Б. Кістяківський, О. Орлова, В. Семенов, Л. Трушкіна та ін. наголошують на необхідності здійснення комплексного підходу до проблеми підготовки юристів, на важливості урахування виховного аспекту. Осмислення специфіки підготовки юристів здійснюється у низці робіт учених-юристів (В. Горшенев, С. Сливка, В. Хома, В. Царенко).

Учені А.Борейчук, В. Васильєва, В. Молдаван, О. Калита, Н. Кожем'яко та інші науковці розглядають використання освітньо-діяльнісної технології як одну із умов підготовки майбутніх юристів до професійної діяльності. Наукові положення, висновки та рекомендації, надані у цих дослідженнях, мають велику цінність для вирішення завдань щодо підготовки майбутніх юристів.

Результати аналізу наукових праць із зазначеної проблеми дозволяють зробити висновок, що оптимізації підготовки майбутніх юристів до професійної діяльності сприятиме використання новітніх технологій, орієнтованих на вивчення прав i свобод людини, ознайомлення 3 нормативно-правовою базою держави, юридичною термінологією тощо.

Виокремлення невирішених раніше аспектів загальної проблеми, які суголосні із статтею. Педагогічна технологія функціонує як наука, що досліджує найраціональніші шляхи навчання, і як система способів, принципів і регулятивів, 
які застосовують у навчанні, і як реальний процес навчання [1, с. 66]. Потреба у розробленні педагогічних технологій виникла у зв'язку 3 ідеєю управлінням педагогічним процесом.

Педагогу недостатньо знати методику, він повинен уміти трансформувати знання і вміння, тобто володіти технологією отримання запланованого результату. Суттєвою особливістю педагогічної технології $\epsilon$ гарантування кінцевого результату і проектування навчального процесу $[1$, с. 71$]$. У нашому випадку кінцевий результат - це підготовленість майбутніх юристів до професійної діяльності. Проектування процесу підготовки майбутніх юристів передбачає чітке визначення мети, змісту, методів, прийомів, засобів цього процесу, взаємозв'язків та взаємозалежності між його учасниками.

У сучасній педагогіці розроблено низку технологій навчання, які різняться цілями та особливостями методики. Під час викладання конкретної дисципліни педагог створює власну авторську технологію навчання. При цьому педагогічна майстерність полягає в тому, щоб дібрати необхідний зміст, застосувати оптимальні методи і засоби навчання відповідно до програми і поставлених освітніх цілей [2].

До традиційних технологій умовно можна віднести пояснювальноілюстративне навчання. Воно забезпечує сприймання студентами коледжу навчальної інформації з одночасним їі узагальненням, засвоєнням понять, законів, теорій. Використовувані практичні вправи покликані забезпечити поглиблення, закріплення знань, умінь і навичок, застосування їх у нових ситуаціях. Ця технологія забезпечує всебічне та міцне засвоєння навчальної інформації й оволодіння способами практичної діяльності [2].

Щодо проблемного навчання, цей вид навчання передбачає послідовні й цілеспрямовані пізнавальні завдання, які студенти коледжу розв'язують під керівництвом викладача й активно засвоюють нові знання. Суть такого навчання полягає у формулюванні проблемних завдань, проблемному викладі й поясненні знань педагогом, у різноманітних формах роботи студентів. Завдання стає пізнавальною проблемою, якщо воно потребує роздумів, викликає в студентів пізнавальний інтерес, спирається на попередній досвід i знання за принципом апперцепції - залежності сприймання від минулого досвіду, наявних в студентів уявлень і знань для більш точного засвоєння нового матеріалу.

Для реалізації завдань підготовки юристів дослідники пропонують такі форми та методи, як словесні: лекції $з$ проблемним викладом знань, 3 опорою на самостійну роботу студентів, 3 елементами евристичної бесіди, лекція-візуалізація, лекція із заздалегідь запланованими помилками (теми: "Походження і сутність держави i права", “Конституційне право”, “Цивільне право”, “Сімейне право”, “Трудове право", "Процесуальне право", "Правова держава: теорія, проблеми становлення" та ін.); семінарські заняття (теми: “Твій імідж”, “Мистецтво спілкування", "Твоя поведінка у громадських місцях", “Як знайти гідний вихід із складних ситуацій”), пізнавально-творчі (вирішення пізнавальних правових завдань, вправи, захист проектів, прес-конференція, турнір знавців права, КВК, заочна подорож, бій правознавців, підготовка рефератів, конспектів першоджерел), дискусійні (проблемний виклад матеріалу, практикуми, диспути, дискусії та ін. (теми: "Солдати порядку” (про роботу міліції), “Людина і суспільство”, “Права та обов'язки молодих спеціалістів, їх працевлаштування", “Вільна людина у вільному світі”, “Азбука права" (знайомство із законодавством), "Перша Конституція України") тошо) [3, 
с. 10]. Аналіз перерахованих форм та методів навчання свідчить, що в основі кожної 3 них покладено взаємодію між учасниками процесу навчання.

Оскільки активну взаємодію всіх учасників процесу навчання, їх здатність до діалогу з будь-чим (комп'ютером) або з будь-ким (людиною) передбачають інтерактивні освітні технології, то постає питання про обгрунтування доцільності використання інтерактивних технологій у підготовці майбутніх юристів .

Формулювання цілей статті (постановка завдання). Метою статті $\epsilon$ обгрунтування доцільності використання інтерактивних технологій у підготовці майбутніх юристів.

Виклад основного матеріалу дослідження 3 повним обгрунтуванням одержаних наукових результатів. На доцільності застосування форм і методів інтерактивного навчання у підготовці фахівців наголошували Р. Гуревич, О. Коберник, Л. Коваль, В. Мельник, І. Мельничук, О. Пометун.

Термін “інтерактиву” походить від англійського “interact”, що у перекладі означає: "inter" - взаємний та "асt" - діяти [4, с. 109]. Він означає постійну й активну взаємодію усіх учасників процесу.

Як зазначають $Є$. Коротаєва [5] та О. Янкович [6], інтерактивне навчання $€$ таким, що побудоване на взаємодії студента з навчальним оточенням, навчальним середовищем, яке служить сферою освоєння досвіду; досвід студента-учасника служить центральним джерелом навчального пізнання. На думку I. Мельничук, інтерактивним є навчання, що розуміється як спільний процес пізнання, де знання видобувається в спільній діяльності через діалог, полілог студентів між собою і викладачем [7]. Водночас, М. Кадемія, вважає інтерактивним навчання, яке засноване на психології людських взаємин і взаємодій [8].

Інтерактивне навчання вчені розглядають як спосіб пізнання, що базується на спільній діяльності всіх учасників освітнього процесу, спільному вирішенні проблем та моделюванню проблемних ситуацій у діяльності, оцінці дій колег і своїх власних [9, с. 124]. У контексті підготовки майбутніх юристів до професійної діяльності в коледжах вагомими $є$ висновки Е. Коротаєвої про три функції інтерактивного навчання: навчально-пізнавальну; комунікаційно-розвиваючу; соціально-орієнтаційну [5, с. 132-143].

Як зазначає О. Пометун, у контексті інтерактивного навчання знання набувають іншої форми [10, с. 7]. 3 одного боку, вони $\epsilon$ певною інформацією, особливістю якої $є$ те, що студент одержує її не у вигляді вже готової системи від викладача, а в процесі власної активності. 3 іншого боку, у процесі взаємодії на занятті з іншими учасниками процесу навчання майбутній фахівець опановує систему випробуваних (апробованих) способів діяльності стосовно себе, колег, підлеглих, засвоює різні механізми пошуку знань в індивідуальній і колективній діяльності. Тому отримані знання $є$ одночасно й інструментом для самостійного їх здобування i для пошуку шляхів їх практичної реалізації.

Нами було враховано підхід, що мета інтерактивного навчання - створення педагогом умов навчання, за яких студент сам відкриватиме, здобуватиме й знання та здійснюватиме самопідготовку до професійної діяльності. Саме це, на думку О. Пометун, становить принципову відмінність цілей інтерактивного навчання від цілей традиційної системи освіти [10, с. 8].

Існує наукова позиція, що ефективність фахової діяльності викладача вищого навчального закладу визначається його активною взаємодією зі студентами, реалізацією ним доцільних психолого-педагогічних впливів, що сприяють якісному 
оволодінню студентами сучасними фаховими знаннями, вміннями та навичками, а також формуванню в них особистісних якостей і властивостей, необхідних для майбутньої професійної діяльності, суспільного та громадського життя [11, с. 88].

Кожний навчальний заклад створює свою базу найбільш часто використовуваних інтерактивних технологій із врахуванням специфіки особливостей спеціальностей, фахівців з яких готує конкретний навчальний заклад, педагогів, контингенту студентів, матеріально-технічного забезпечення та ін. Сукупність цих інтерактивних технологій утворює методичну скарбницю, як кожного конкретного навчального закладу, так і освітньої системи загалом. У цьому контексті доречним є досвід використання низки інтерактивних технологій у підготовці майбутніх юристів в коледжах, зокрема при проведенні занять 3 історико-теоретичних юридичних дисциплін.

Підготовка майбутніх юристів передбачає поглиблене вивчення низки історико-теоретичних, галузевих юридичних навчальних дисциплін, що дозволяє широко застосовувати інтерактивні методи і методичні прийоми.

Доцільним є використання образних (наочні приклади, факти з життя відомих людей, самих студентів, пов'язані з правовими явищами, художні твори, розповіді очевидців, ситуації-моделі, ситуації-зразки); ігрових (сюжетно-рольові, ділові, творчі ігри, ігри-подорожі, ігри-імітації, вікторини, тренінги "Правова держава", “Забезпечення прав і свобод людини і громадянина. Як це здійснюється”), технічних (демонстрація відеосюжетів, радіо- і телепередач, телешоу, художніх і документальних фільмів “Серед білого дня”, “Дитячі банди”); колективно-творчих (колективна творча справа, виставки: "Ресурси бібліотеки в боротьбі з корупцією”, “Юридичні консультації засобами Інтернет”, творче свято, інсценування оповідань, судових процесів, правових явищ, усний журнал, стінгазета, газета-блискавка, журнал-естафета, конкурс студентських творчих робіт правового спрямування 3 тем: "Вступ до різних політичних організацій", "Правова культура студентів та шляхи іiі реалізації в коледжі”, “Протидія торгівлі людьми”, “Укладання трудового договору. Як не стати жертвою афер", “Як не стати жертвою злочину"), діяльнісних (патрулювання території, шефство над учнями, що порушують дисципліну, виступ із правовими повідомленнями, участь у роботі студентського клубу) методів та форм навчання [3, c. 11]. Відомо, що особливістю останніх $є$ спонукання учасників навчальновиховного процесу до активності та взаємодії.

Існують дві форми інтеракції. Перша $є$ заздалегідь підготовленою, друга імпровізованою, яка, порівняно $з$ першою, виникає випадково під час обговорення певних навчальних проблем. Було взято до уваги висновки I. Романюка про найбільшу перспективність інтерактивних ігор, які науковець поділяє: на імітаційні та рольові [12, с. 135].

Інтерактивні технології передбачають низку методів вивчення історико-теоретичних юридичних дисциплін, одним із яких $є$ метод “групового обговорення". Методика підготовки та проведення такого заняття досить проста. Студенти навчальної групи розсідаються по групах 3 5-6 чоловік. Кожна група отримує завдання - одне 3 навчальних питань за планом заняття - i приступає до його групового обговорення протягом 10-15 хвилин. При цьому студенти не використовують підручників, але можуть працювати 3 конспектами та хрестоматійним матеріалом. Викладач надає допомогу студентам, за необхідності консультує їх з проблемних питань. Студенти роблять записи в конспектах. Коли групове обговорення закінчується, по одному студенту 3 кожної групи пересідають за першу парту і письмово викладають свої 
думки за результатами групового обговорення. У цей час починається усне опитування. Від кожної групи (за бажанням студентів, чи за вимогою викладача) один представник відповідає на запитання, яке обговорювалось. Викладач уважно слідкує за відповіддю, за ходом його думки, помічає недоліки, які допускає доповідач під час відповіді, занотовує їх, оскільки в разі не грубих помилок у доповіді не рекомендується перебивати доповідача. Решта студентів, уважно слухають, у готовності доповнити відповідь. Після закінчення відповіді на поставлене питання, викладач дає змогу іншим за їх бажанням, доповнити відповідь доповідача, задати йому додаткові запитання, уточнити найбільш важливі моменти за змістом відповіді, виправити, за необхідності, якщо доповідач помилився чи був неточним під час відповіді. Після відповіді студента викладач ставить проблемні питання і організовус дискусію при безперервній і максимальній увазі та високій активності аудиторії. За відсутності доповнень, викладач викликає для відповіді на нерозкриті аспекти питання іншого студента з групи, яка обговорювала це питання, згідно списку класного журналу.

Згідно класифікації інноваційних методів навчання, запропонованої В. Морозовим, останні поділяються на проектні, лабораторні та інтегровані [13, с. 37]. Метод "групового обговорення" є інтегрованим (комплексним), оскільки передбачає здійснення навчання за певними темами-комплексами, що містять матеріали суміжних предметів. Саме тому цей метод є ефективним у підготовці майбутніх юристів до професійної діяльності, зокрема для вивчення юридичних дисциплін історичного та теоретичного блоку. Обговорюючи проблемний матеріал 3 цих навчальних дисциплін, майбутні юристи мають змогу застосовувати теоретичні знання, практичні уміння щодо роботи 3 юридичними документами та джерелами. Відтак, використання методу “групового обговорення" відповідає головному призначенню процесу підготовки майбутніх юристів - розвитку самостійного юридичного (професійного) мислення, комунікативних умінь та навичок, що є важливим для формування професіоналізму майбутнього юриста.

Безумовно, успішне запровадження інтерактивних технологій у підготовку майбутніх юристів вимагає системної роботи, для якої необхідно по-перше, переглянути зміст підвищення кваліфікації педагогічних кадрів з метою формування їх професійної готовності до роботи в умовах інтерактивного навчання; по-друге, наблизити навчально-виховний процес до реальних вимог майбутньої професійної діяльності юристів.

Висновки представленого у статті дослідження і перспективи подальших наукових розвідок із зазначеного напряму.

Отже, доцільність використання інтерактивних технологій у підготовці майбутніх юристів визначається специфічними особливостями цього процесу та вимогами, які пред'являє суспільство до професійних якостей фахівців-юристів. Проведене дослідження не претендує на висвітлення всіх аспектів проблеми підготовки майбутніх фахівців юридичної сфери. Тому перспективним $є$ детальне вивчення форм та методів підготовки майбутніх фахівців юридичної сфери на різних iii етапах, визначення та обгрунтування педагогічних умов ефективного перебігу зазначеного процесу.

Література
1. Дичківська I. М. Інноваційні педагогічні технології : навчальний посібник. К. : Академвидав, $2004.356 \mathrm{c}$.

2. Технології навчання. URL: http:/ tudies.in.ua/ru/pedagogika-shpargalki/1416-tehnologyinavchannya.html 
3. Коваль І.В. Правове виховання студентів у навчально-виховному процесі педагогічного коледжу: автореф. ... канд.. пед..наук : 13.00.07. Умань, 2016, 20 с.

4. Шевченко А. В. Формування фахової компетентності майбутніх офіцерів тилу в процесі професійної підготовки : дис. ... канд. пед. наук : 13.00.04. Хмельницький, 2016. 279 с.

5. Коротаева Е. В. Технология обучения в интерактивном режиме. Мир образования. 2013. № 4. C. $132-143$.

6. Янкович О. І. Освітні технології вищої школи України: проблеми та перспективи : монографія ; за ред. В. М. Чайки. Тернопіль : Підручники і посібники, 2010. 208 с.

7. Мельничук I. М. Теорія і практика професійної підготовки майбутніх соціальних працівників засобами інтерактивних технологій : дис. ... доктора пед. наук : 13.00.04. Тернопіль, 2011 $584 \mathrm{c}$.

8. Кадемія М. Ю. Використання ділових ігор в навчальній діяльності. Сучасні інформаиійні технології та інновачійні методики навчання у підготовиі фахівців: методологія, досвід, проблеми : збірник наук, праць. Вінниця, 2008. Вип. 20. С 213-217.

9. Мірошніченко А.А. Методика формування фахових командирських компетентностей майбутніх офіцерів-прикордонників у процесі вивчення загальновійськових дисциплін: дис. ... канд.пед.наук . Хмельницький, 2018. 284 с.

10. Пометун О. І. Енциклопедія інтерактивного навчання. Київ, 2007. 144 с.

11. Терлецька Ю. Ефективність фахової діяльності викладачів вищих навчальних закладів: педагогічно-психологічний аспект. Вища икола. 2014. № 1. С. 81-89.

12. Романюк I. М. Використання ігрових технологій у вищій школі. Вісник Національного університету оборони Украйни : зб. наук. праць. Київ : НУОУ, 2013. Вип. 6 (37). С. 131-136.

13. Morozov V. The philosophy innovation in teaching process. Higher education Ukraine. 2014. № 2. p. $36-39$

\section{References}

1. Dychkivska I. M. Innovatsiini pedahohichni tekhnolohii : navchalnyi posibnyk. K. : Akademvydav, $2004.356 \mathrm{~s}$

2. Tekhnolohii navchannia. URL: http:// tudies.in.ua/ru/pedagogika-shpargalki/1416-tehnologyinavchannya.html

3. Koval I.V. Pravove vykhovannia studentiv u navchalno-vykhovnomu protsesi pedahohichnoho koledzhu: avtoref. ... kand.. ped..nauk : 13.00.07. Uman, 2016, $20 \mathrm{~s}$.

4. Shevchenko A. V. Formuvannia fakhovoi kompetentnosti maibutnikh ofitseriv tylu v protsesi profesiinoi pidhotovky : dys. ... kand. ped. nauk : 13.00.04. Khmelnytskyi, 2016. $279 \mathrm{~s}$.

5. Korotaeva E. V. Tekhnolohyia obuchenyia v ynteraktyvnom rezhyme. Myr obrazovanyia. 2013. № 4. S. 132-143.

6. Yankovych O. I. Osvitni tekhnolohii vyshchoi shkoly Ukrainy: problemy ta perspektyvy : monohrafiia ; za red. V. M. Chaiky. Ternopil : Pidruchnyky i posibnyky, 2010. $208 \mathrm{~s}$.

7. Melnychuk I. M. Teoriia i praktyka profesiinoi pidhotovky maibutnikh sotsialnykh pratsivnykiv zasobamy interaktyvnykh tekhnolohii : dys. ... doktora ped. nauk : 13.00.04. Ternopil, 2011.584 s.

8. Kademiia M. Yu. Vykorystannia dilovykh ihor v navchalnii diialnosti. Suchasni informatsini tekhnolohii ta innovatsiini metodyky navchannia u pidhotovtsi fakhivtsiv: metodolohiia, dosvid, problemy : zbirnyk nauk, prats. Vinnytsia, 2008. Vyp. 20. S 213-217.

9. Miroshnichenko A.A. Metodyka formuvannia fakhovykh komandyrskykh kompetentnostei maibutnikh ofitseriv-prykordonnykiv u protsesi vyvchennia zahalnoviiskovykh dystsyplin: dys. ... kand.ped.nauk . Khmelnytskyi, 2018. 284 s.

10. Pometun O. I. Entsyklopediia interaktyvnoho navchannia. Kyiv, 2007. $144 \mathrm{~s}$.

11. Terletska Yu. Efektyvnist fakhovoi diialnosti vykladachiv vyshchykh navchalnykh zakladiv: pedahohichno-psykholohichnyi aspekt. Vyshcha shkola. 2014. № 1. S. 81-89.

12. Romaniuk I. M. Vykorystannia ihrovykh tekhnolohii u vyshchii shkoli. Visnyk Natsionalnoho universytetu oborony Ukrainy : zb. nauk. prats. Kyiv : NUOU, 2013. Vyp. 6 (37). S. 131-136.

13. Morozov V. The philosophy innovation in teaching process. Higher education Ukraine. 2014. № 2. p. 36-39. 